УДК 811.161.1

ББК 81.2

DOI: https://doi.org/10.17308/lic.2021.4/3821

\title{
ПРЕЦЕДЕНТНЫЙ МЕТОД СЛОГОДЕЛЕНИЯ И ТИПЫ ФОНЕТИЧЕСКИХ И ФОНЕМИЧЕСКИХ СЛОГОВ В СОВРЕМЕННОМ РУССКОМ ЛИТЕРАТУРНОМ ЯЗЫКЕ
}

\author{
А. А. Кретов \\ Воронежский государственный университет

\begin{abstract}
PRECEDENT METHOD OF SYLLABLE DIVISION AND TYPES OF PHONETIC AND PHONEMIC SYLLABLES IN MODERN STANDARD RUSSIAN
\end{abstract}

\author{
A. A. Kretov \\ Voronezh State University
}

\begin{abstract}
Аннотация: статья посвящена результатам исследования А. И. Моисеева 1975 г., дающим хорошую возможность оценить эффективность и научную состоятельность прецедентного метода слогоделения на достоверном и репрезентативном материале односложных лемм Малого академического словаря. Показывается различие фонетического и фонемического слога. Предлагается различать слоги в исконных, заимствованных и звукоподражательных словах. Дается классификация фонем и иерархия различительных признаков фонов, исчисление силлабем и слоготипов в русском фонемическом слоге. Обнаруживаются дифтонги ${ }^{e} \mathrm{P},{ }^{\circ} \mathrm{P},{ }^{e} Л,{ }^{\circ} Л$, встречающиеся под ударением и реализуюшие слоговой вариант сонантов. Определяется максимальный размер инициали фонемического слога (4 элемента) и финали (1 элемент) в исконных словах. Все «тяжелые» финали слога обнаруживаются в заимствованных словах. В исконных словах мнимые тяжелые финали являются инициалями слога с нулевым вокалом. Описывается «цементирующая» (по И. А. Бодуэну де Куртенэ) функция русского слога, состоящая в несовпадении грании слога и морфемы внутри слова и, напротив, в их совпадении на границах слов. Оказывается, что самим языком так называемый «постфикс» -ся трактуется как самостоятельное слово и самостоятельный член предложения, а отрицательные частицы не (в не-кто), ни (в ни-кто) и глагольные приставки на гласный - как самостоятельные (пусть и служебные) слова, так и не ставшие частью современного русского слова (сколько бы мы их ни писали слитно). Исключением из этого правила является архаичный суффиксальный стык глагола после степенных суффиксов: $=$ ну, $=u,=e,=a$, свидетельствуюший об архаичности и хорошей (с индоевропейских времен) сохранности структуры русского глагола. Итогом анализа является вывод, что исследования А. И. Моисеева наглядно демонстрируют научную несостоятельность прецедентного метода слогоделения.

Ключевые слова: слог, прецедентная теория слогоделения, волновая теория слога, классификация фонем по их порядку следования в слоге, иерархия различительных признаков в свете силлабологии, дифтонги в русском языке, типы фонемических слогов в русском языке.
\end{abstract}

Abstract: the paper considers the results A. I. Moiseev obtained in 1975. They allow evaluating the efficacy and scientific correctness of precedent method of syllable division basing on the study of one-syllable stems Small General-Purpose Dictionary contains. The author reveals the difference between phonetic and phonemic syllables and proposes differentiating syllables in native, borrowed and onomatopoetic words. The paper also presents the classification of phonemes, the hierarchy of phones distinctive features, syllabeme and syllable type calculus in a Russian phonemic syllable. The author points out that the following diphthongs such as ${ }^{e} \mathrm{P},{ }^{\circ} \mathrm{P},{ }^{e} Л,{ }^{\circ} Л$ realize a

(C) Кретов А. А., 2021

Контент доступен под лицензией Creative Commons Attribution 4.0 License.

The content is available under Creative Commons Attribution 4.0 License. 
syllabic sonant in stressed position. Then the author specifies maximum size of a phonemic syllable initial (4 elements) and a final (1 element) in native words. All 'heavy' finals belong to borrowed words. In native words, pseudo-heavy finals are initials in the syllable possessing a zero voiced sound. The paper describes 'cementing' (according to Baudouin de Courtenay) function of a Russian syllable. It means a dissimilarity of syllable and morpheme boundaries within a word and their exact match at words boundaries. It appears that the language itself regards a so-called 'postfix'-cr as both a separate word and a separate member of a sentence. At the same time, it regards both negative particles не (e.g. не-кто), ни (е.g. ни-кто) and verbal prefixes ended in a vowel as separate (albeit functional) words which haven't become the part of a Russian word despite their being written in one word for a long time. The only exception is a verb archaic suffixal juncture after such power suffixes as $=H y,=u,=e,=a$. This fact indicates that the structure of a Russian verb is archaic and, since Indo-European times, withstand the ravages of time. The study results in the conclusion that A. I. Moiseev's studies clearly demonstrate the failure of a precedent method of a syllable division.

Key words: syllable, precedent theory of syllable division, wave theory of syllable, classification of phonemes according to their order in the syllable, hierarchy of distinctive features in terms of syllabology, Russian diphthongs, types of phonemic syllables in the Russian language.

\section{Введение. Проблема прецедентного метода слогоделения}

Одним из древнейших методов слогоделения, идущим из античности через М. В. Ломоносова, Ф. де Соссюра [1] и Е. Куриловича, является прецедентный метод, основанный на стремлении исследователей опереться при делении слова на слоги на свидетельства самого языка. Этот подход основан на допущении, что начало слога по своему строению тождественно началу слова, а конец слога - концу слова. Е. Курилович пишет: «Как следует оценить такой метод? Эффективность его оказывается лишь частичной» [2, с. 268], - и все же строит на нем свою концепцию.

Давно известно, что есть законы начала слова и есть законы конца слова, которые связаны с необходимостью маркировать границы слов в потоке речи. В этом смысле начало и конец слова морфологизированы, и допущение об их тождественности началу и концу слогов, находящихся в середине слова, не представляется оправданным.

Можно попробовать «китайский» или точнее «прецедентный» подход: исследовать строение односложных слов. Но и в этом случае нет гарантии, что односложные слова и слоги устроены тождественно: односложным словам пограничные сигналы необходимы так же, как и многосложным. Известны случаи влияния морфонологических явлений на односложные слова. Например, беглость гласного в слове лёд-льда (при лит. ledús 'лёд') или лев-льва (при д.-в.-н. lëwo, < лат. lēo, греч. $\lambda \dot{\varepsilon} \omega v)$ [3, т. 2, с. 471] появляется как с игнал конца слова: «вокализм а н а л о г и ч е с к о г о происхождения, подобно лён, льна и другим случаям» [там же, с. 474]. Аналогия же-механизм морфологической системы, способ реализации интересов морфологии.

На это указывает и Р. И. Аванесов: «...в конечном счете различные типы слогов в русском языке определяются закономерностями начала неначального слога, конца неконечного слога, начала начального слога и конца конечного слога» [4, с. 101]. Как видим, по Аванесову, терминальные (начальные и конечные) слоги и нетерминальные (неначальные и неконечные) обладают разными закономерностями, а следовательно, терминальные слоги не могут помочь в познании нетерминальных.

\section{Материалы и методы}

Для оценки разрешающей способности прецедентного метода в русском языке обратимся к данным А. И. Моисеева, без малого полвека тому назад предпринявшего интересную и в целом продуктивную попытку описания русского слога, обойдя проблему слогоделения $[5]^{1}$. Для этого он обратился к односложным леммам (словарным формам). В MACе-1 [6], по данным А. И. Моисеева, таких слов оказалось $\approx 3150$, что представляется вполне репрезентативным множеством. Конечно, привлечение «текстовых слов», представленных на письме последовательностям букв между двумя пробелами, позволило бы уточнить, дополнить и отчасти скорректировать эти данные, но едва ли изменило бы их кардинально.

Материал А. И. Моисеева и его интерпретация дают хорошую возможность аргументированно оценить эффективность и научную состоятельность прецедентного метода, что и является целью данной статьи.

В целом позиция и подход А. И. Моисеева к анализу русских слогов нам близки. Возражение вызывают следующие положения.

1. Неразличение исконной и заимствованной лексики, которая, как и звукоподражательная, не обязана соблюдать законы русской фонетики.

2. Неразличение по «звучности» фрикативных и эксплозивных согласных и как следствие - допущение

${ }^{1}$ Строго говоря, А. И. Моисеев всё же решил проблему слогоделения: фактически для него слог - это словарная форма, содержащая один гласный. 
(вслед за Р. И. Аванесовым [4] и М. В. Пановым [7; 8]) «плато звучности» - «равнозвучных» участков в слоге.

3. «Практически, например при изучении слогоделения, приходится иметь дело главным образом с двучленным противопоставлением позиционных типов слогов: начальный слог - неначальные слоги, в их числе и конечный; конечный слог - неконечные слоги, в их числе и начальный» [5, с. 114]. К азам компаративистики относится различение начальной, срединной и конечной позиций звуков в слове [9, с. 323]. Не менее важно это различение и для теории слога.

Начальные слоги в русском языке отягощены проклитиками в самом широком их понимании, включая приставки. Что искажает структуру инициали слога.

Кон ечны е слоги (особенно их финали) не только могут быть осложнены энклитиками, но и содержат морфологические ограничения на количество и качество звуков, что также сказывается на конечных слогах.

С рединные слоги максимально свободны от морфологических обременений, что и делает их полноценными (эталонными) представителями системы русских слогов. Правда, это означает, что по началу-концу слова нельзя судить об инициали-финали слога, и требует поиска иного критерия слогоделения.

Попробуем такой критерий найти.

\section{Результаты исследования}

Главная оппозиция звуков в слоге: «слогообразующий звук в отличие от не-слогообразующих». Доказательство простое: без слогообразующего звука слога не бывает, а без не-слогообразующих - бывает: $u, a, y, o$, э(-mo) и даже «Операция “ $D I^{\prime}$ " и другие приключения Шурика».

При этом нередко ставят знак равенства между слогообразующими и гласными (обозначая их символом Г), не-слогообразующими и согласными (обозначая их символом С).

Кроме гласных - вокалов, всегда образующих слог, и согласных - консонантов, никогда не образующих слога, существует промежуточное множество фонем - сонанты, которые в зависимости от позиции в речевой цепи могут образовывать слог или не образовывать его. Образуют слог сонанты в окружении консонантов ( $\left.{ }^{E} P x, y^{\ddot{E}} Л н, 2^{O} P c m b, \partial^{O} Л z\right)$ или после консонантов на конце слова (ве́- $\left.m^{e} P, \sigma a 2^{O} P, б о \sigma^{\ddot{E}} p\right)$ и не образуют его - в соседстве с вокалом (ве́-тра, багра́, бо-бра́) $)^{2}$. Таким образом, сонанты обладают

\footnotetext{
2 При этом слоговость б е з уда р н о го сонанта факультативна (совсем как у французской фонемы «ә» [10, с. 101111]). Ср. у А. В. Кольцова: «Густолиственный Твой зеленый илем Буйный вихрь сорвал - И развеял в прах» («Лес») и «Царь-ханжа летит, как вихорь, С саранчою удальцов Москву-матушку пилатить - Кушать мясо и пить кровь!» (Русская песня, «В Александровской слободке...»).
}

свойствами как вокалов, так и консонантов, представляя тем самым нейтрализацию оппозиции «слоговой : неслоговой» и доказывая фактом этой нейтрализации существование такой оппозиции. Сонанты (в зависимости от позиции) - то слоговые, то неслоговые, а в общем случае - ни те, ни другие.

Именно сонанты обеспечивают целостность системы фонем. Особенно ярко это проявляется в том, что слоговые варианты глайдов И/Й, У/В - /И/, /У/ традиционно относят к гласным, а их неслоговые варианты - /Й/, /В/ относят к согласным. Правда, при этом приходится делать оговорки, чтобы объяснить, отчего глухие консонанты перед «звонким согласным» /В/ не озвончаются: ответ, а не * овет, свет, а не *3вет, квас, а не * Гвас и т. д.

Итак, первый принцип классификации звуков в слоге - способность к слогообразованию, равная «плюсу» - у вокалов, равная «минусу»-у консонантов и равная «нулю» - у сонантов.

Второй по значимости принцип классификации звуков в слоге был подмечен еще Ф. де Соссюром: это принцип, связанный с физиологическим субстратом речи: смыканием-размыканием (имплозией-эксплозией) [1]. Для произнесения фрикативных консонантов надо разомкнуть рот - образовать щель, проходя сквозь которую, воздух будет тереться и образовывать свистящий или шипящий звук. Для произнесения эксплозивных консонантов, наоборот, надо закрыть рот, создав смычку, преграду, прорывая которую, воздух образует «взрывной» консонант.

Открыть можно только закрытый рот, а закрыть только открытый. Так физиологический субстрат требует чередования смыканий-размыканий рта (имплозии и эксплозии). Именно поэтому соседство «смыкателей» рта, как и соседство «размыкателей», вызывая артикуляционное неудобство, имеет тенденцию к устранению. Примеры в самых разных языках многочисленны. Немало их и в русском (примеры даны ниже).

Итак, консонанты подразделяются на два множества: размыкатели и смыкатели. Для того чтобы произнести фрикативный, нужна более сильная струя воздуха и большее усилие, чем для того, чтобы произнести эксплозивный консонант. Видимо, поэтому фрикативные в инициали слога предшествуют эксплозивным.

Самую «тяжелую» (4-членную) инициаль имеют слоги -СТВЛЯТЬ, -СТВЛЯЙ, -СТВЛЁН и -СТВЛЯЛ в формах о-су-щ̧е-СТВЛЯ(ТЬ/Й/Л) - о-су-щуе-СТВЛЁН. Рассмотрим, как устроена эта инициаль, обозначая имплозию символом «<» (размыкатель), а эксплозию - символом «>» (смыкатель):

$\mathrm{C}-\mathrm{T}-\mathrm{B}-Л-$ Я $-\mathrm{T}^{\mathrm{b}}$

$<->-<->-<->$ 
При этом отметим, что способность к слогообразованию важнее (имеет приоритет относительно) способа образования: вокалы (размыкатели рта) сочетаются как с фрикативными (размыкателями), так и с эксплозивными (смыкателями) консонантами/сонантами.

Однако, как только это основание снимается, в силу вступает способ образования - фр и кат и в ны е консонанты не сочетаются: предшествующий фрикативный полностью уподобляется последующему: сиить /ш:ыт', изжить /иж:ыт'/. Не сочетаются и смычные консонанты, сходные по месту образования - nодтопить /пат:ап'Ит', предшествующий взрывной уподобляется последующему по глухости/звонкости (символ долготы «:» обозначает удлинение выдержки - двух взрывов подряд не происходит); ср. также к косому /к:асОму/. Другой способ устранения соседства смычных консонантов - «понижение», т. е. превращение предшествующего смычного в щелевой: лёгкий /л'Охк'ий/; мягкий /м'Ах'к'ий/ (орфография не должна нас обманывать: формы мяКоть, мяКнуть и др. указывают на фонему $\{K\}$, и следование морфемному принципу

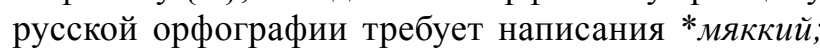
следование же фонетическому принципу требует написания * мяхкий, но никак не мягкий); несу-нести, но плету - плеСти, а не *nлеТти, мету - меСти, а

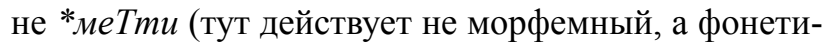
ческий принцип орфографии).

Интересно было бы исследовать позиции, в которых предпочитается тот или иной способ устранения соседства смычных.

Взаимодействие смычности у консонантов и сонантов также имеет место, правда, оно в значительной степени морфологизировано и проявляется не столь последовательно.

Хорошо известна, в частности, несовместимость смычных консонантов с сонантом /л/: мету, но мёл, а не * невозможны, потому что при артикуляции /л/ имеется смычка языка с зубами.

Слова све-тло, ме-тла и се-дло не являются контраргументами: между /т/-/д/ и /л/ у них имеется беглый $/ \mathrm{e} /=\{\mathbf{b}\}:$ светёлка, метёлка, седельник (и многие другие). Не являются контраргументами и заимствования типа $a-m л а с, a-m м о-c ф e-p a$, бы-дло и т. п.

Интересно влияние смычности-щелинности на сочетаемость сонантов внутри слога.

Во-первых, это всегда сочетаемость носовых (М-Н) с плавными (Р-Л).

Во-вторых, такие слоги встречаются только в южно-славянской подсистеме, обычно - как результат неполногласного преобразования сочетаний с плавными: МРак-МРеть, МЛад-МЛе-чный, НРав.
При этом носовые трактуются как смычные, а плавные - как щелевые.

Интересно, что сочетание НЛ внутри слога не встречается, видимо, потому, что в слоге МЛе- М губной, а Л - дентальный, тогда как в сочетании НЛ оба звука дентальные и П-принцип запрещает такое сочетание.

Примеры, со нли $\mid$ вый, чва|нли|вый и т. п. не показательны: между Н и Л есть беглый гласный $\{\mathrm{b}\}$, что подтверждается чередованиями Г:Ж, К:Ч, Х:Ш, свидетельствующими о первой палатализации перед суффиксом =БЛИВ в словах береГу : береЖливыци, драКа : драЧливый, смеХ : смеШливый. (Исключения, образованные от звуко подражаний, например, крик : крикливыцй ментом не являются).

Фактически фон /ж/ в слове бережсливый выполняет две функции: представляет консонант $\{\Gamma\}$ (ср. берегу) и вокал $\{\mathrm{b}\}$ в его закономерно нулевом (перед слогом с /и/) варианте: /ж/гь. Соответственно, фон /ш/ в слове смешливый представляет консонант $\{\mathrm{X}\}$ (ср. cмех) и вокал $\{\mathrm{b}\}: / ш /{ }^{\text {хь }}$, а фон /ч/ в слове драчливыц представляет консонант $\{\mathrm{K}\}(\mathrm{cp} . \partial р а к а)$ и вокал $\{\mathrm{b}\}$ : $/ \mathrm{ч} /$ кь

Когда к одинаковой способности к слогообразованию добавляются одинаковый способ и одинаковое место артикуляции, сочетаемость становится невозможной.

В качестве контаргумента можно привести формы П-Тa-хa, T-Кать, в которых сочетаются два смычных консонанта, или $\mathrm{MHy}, \mathrm{MHe}^{4}$, в которых сочетаются два носовых сонанта.

Первое, на что хотелось бы обратить внимание, это различие по месту артикуляции: губной + зубной (акцессивная последовательность: снаружи внутрь).

А во-вторых, между ПТ-, ТК-, МН- есть беглый гласный: ср. диал. «По́тка, ж. 1. Птица (не промышленная), птичка, птаха» [14, вып. 13, с. 284], ТЫКать, сМИНать, МЕНя. Из этого следует, что и в рассмотренных случаях работает принцип: плато звучности - граница слогов .

Место артикуляции можно считать низшим (третьим) уровнем, на котором действует П-принцип.

Таким образом, выстраивается иерархия РП фонов в слоге: 1) способность к слогообразованию; 2) способ образования (смыкатель-размыкатель); 3) место образования. (Низший уровень иерархии

${ }^{3}$ «Все гнездо в целом - звукоподражательного происхождения» [11, вып. 12, с. 156]. Подтверждением этому является суффикс $=$ К, классификатор междометий (cр. $x н b l=K a m b, x u$ -

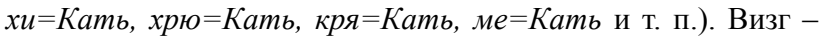
«Звукоподражание» [3, т. 1, с. 313]. В этом слоге суффиксом-классификатором является $=3 Г$. $(\mathrm{cp} . л я=3 Г$, вере $=3 Г$ ‘пронзительный крик, визг’ [12, т. 2, с. 416]).

${ }^{4}$ В слове МНого гласный между М и Н обнаруживается методом внешней реконструкции [3, т. 2, с. 633; 13]. 
применим только к фонам и заимствованным словам.)

У этой иерархии есть фонологическое основание, раскрытое В. Г. Руделевым [15]: 1) позиция перед гласным является самой сильной со звукоразличительной точки зрения: перед гласными встречаются и различаются все сонанты и все консонанты; 2) позиция перед сонантами является сильной для всех консонантов: перед сонантами консонанты различаются по глухости-звонкости; 3) позиция перед смычными - самая слабая в звукоразличительном отношении: во-первых, встречаются только размыкатели перед смыкателями (аффрикаты потому и являются особым случаем, что они позволяют, если не «перепрыгнуть», то «обойти» закон строения слога тем, что аффрикаты оцениваются по началу артикуляции, а не по концу), а во-вторых, в сочетаниях консонантов различаются не фоны, а архифонемы, состоящие из парных по глухости-звонкости фонов: [п/б] (обсblnать /аПсЫпать/, поп Данила /поБ_дан'Иль]); [т/д] (отбить /аДбИт'/, подпустить /паТпус'т'Ит'/); [к/г] (какбь /кАГбы/, бег-то /бЕКть), [с/3] (сбыть /ЗбЫт'/, излить, но испить /иСп'Ит'); [ш/ж] (наш дом /наж_ дОм/, ты ж комик/ты_Ш_кОм'ик/ и противопоставленные друг другу по месту образования (как отмечалось, по способу образования консонанты должны различаться: соседство одинаковых по месту и способу образования консонантов внутри слога недопустимо и устраняется).

Вернемся к исследованию А. И. Моисеева. Рассмотрев все типы инициалей и финалей слога, различаемые исключительно количественно, А. И. Моисеев дает исчисление всех типов теоретически возможных слогов, исходя из (довольно спорного) допущения, что любая финаль может сочетаться с любой инициалью. Более реалистичной была бы гипотеза, что длина слога ограничена величиной оперативной памяти человека 7+/-2.

Обнаружив инициали и финали, состоящие из 4 звуков, и добавив к ним слогообразующий гласный, А. И. Моисеев получил максимальную «теоретическую» длину русского слога в 9 звуков.

Однако реально максимальную длину имели односложные слова и словоформы из 7 звуков - типа всплеск. Сочетаний 3-4-членных инициалей с 3-4-членными финалями среди односложных слов и словоформ обнаружено не было. Не были обнаружены и семизвучные слоги типа сссГссс.

Рассмотрим односложные слова и сравним по отдельности типы инициалей и финалей, встречающихся в них, с типами инициалей и финалей слогов, встречающихся в середине слова.

Начнем с инициалей:

въ|згляд - до-гляд, при-гляд и т. п.

въ $\mid$ спле $\mid$ ск - вы-плеск

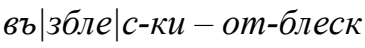

въ

У приставочного морфа вз- имеется алломорф воз-: вз-резать, но воз-разить, вс-крикнуть, но вос-кликнуть. Алломорф вз- принадлежит восточнославянской подсистеме, а алломорф воз- - южнославянской (церковнославянской) подсистеме русского литературного языка. Есть еще и алломорф взо-: взо-браться, взо-рвать, взо-преть, чередующийся с алломорфом вз-: вз-бираться, вз-рывать, вс-париваться.

При феноменологическом подходе А. И. Моисеева начальные слоги могут прикрываться тяжелым и нисходящим началом (слог может быть ломаным). При системном взгляде такие «слоги» оказываются не элементарными, а двойными: первый слог содержит сонант в сочетании с нулевым вокалом:

м|гла, м|гли-ст(ьй) - ср. др.-русск. мьгла, болг. мъгла, серб. ма̀гла, словен. məglà [3, т. 2, с. 587].

м|гно-венье-миг, мигать; др.-русск.мьгнути [3, т. 3, с. 587-588].

ръ|ва-ныле - раз

ль $\mid$ сти-вы-йе - лесть

ръ|жать - рыгать; ст.-слав. ръжж, др.-русск. ръзати, ръжу

ръ

ръ|жав (ьй) - рыюжй

pъ|туть - рутить, рютить [3, т. 3, с. 509-510, $523,533]$

pъ $\mid \partial е т ь-p \boldsymbol{y} \partial а$, рудыı̆

Не следует забывать и о том, что плавные Р-Л это сонанты, которые способны образовывать слог и реализовываться в слоговом варианте, вокалическим пазвуком обозначая слоговость сонанта: например, ир|жа 'рожь', ир|жа 'ржавчина', ир|жаветь 'ржаветь', ир|жать 'ржать (о лошади)' ир|туть 'ртуть' [14, вып. 12, с. 208, 210]; ил|гать 'лгать', ил|гун 'лгун', иль|гота 'льгота', иль $\mid$ ина 'льдина', иль|зя 'можно (т. е. *льзя; ср. литературное нельзя)', иль|стец 'льстец', иль|стить 'льстить' [там же, с. 184, 185, 187]; uм|гa 'мга', им|гла 'мгла', им|гляныц 'мглистый', им|чать 'мчать', им|иина 'мшина (болотце на сухом месте)' [там же, с. 191, 195]. О том, что в данном случае мы имеем дело именно с диезным вокалическим пазвуком сонанта, свидетельствует его позиция: он выделяется пресонантно - перед сонантом. (Типологически этот процесс подобен появлению $\boldsymbol{e}$ - в начале испанского слова с исконно «тяжелой» инициалью первого слога: лат. scho-la > исп. Es-cue-la: в обоих случаях недопустимое в слоге сочетание звуков устраняется созданием нового слога).

Для «темных» слов námльь, nатлатый можно предположить родство с корнем тыл- 'зад' или тьл'дно' и архаичную приставку па́- (ср. па́-трубок, па́-сынок, па́-робок и т. п.). 
Слово длина также содержит гласный (b) между неслоговыми (ср. ст.-слав. продылити [16, с. 73-74]).

Таким образом, мы вправе утверждать, что П-принцип не только объясняет явное, но и помогает видеть скрытое, что согласуется с принципом «хорошее описание языка повторяет в снятом виде его диахронный анализ» [17, с. 12].

Перейдем к рассмотрению «тяжелых» финалей в русских слогах.

Начнем со двучленных финалей в слогах структуры (1-4)512 = (S-R)AST: o|cn; хво $|\mathrm{cm}, \boldsymbol{м о}| \mathrm{cm}$,

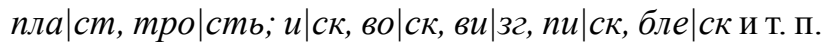

На первый (поверхностный) взгляд эти примеры опровергают наше представление о слоге и наши принципы слогоделения: в них не одна вершина, а две, и не одна, а сразу две волны звучности при одном гласном - это нисходяще-восходящие слоги!

Давайте все же (из чистого любопытства) допустим, что слог имеет одну вершину и только восходящие и/или нисходящие участки «звучности» ${ }^{5}$

В таком случае в этих отрезках должно быть два слога. Один из них открытый, содержащий вокал - с ним все ясно и споров нет.

Сложнее со вторым слогом: /сп/, /ст/, /ст\%/, /ск/. Он состоит из одних консонантов, которые никогда не образуют слога. Слог без слогообразующего элемента невозможен. Следовательно, либо это не слог, либо слогообразующий элемент все же есть.

Если он есть, то где он и какой? Как доказать, что он есть?

Да, слогообразующий вокал есть: это фонема $\{\mathrm{b}\}$, реализующаяся в современном русском языке в виде О-беглого.

Поскольку эта фонема не признана, точнее - не общепризнана, то и описана она недостаточно. Желающих узнать о ней больше отсылаем к публикации [18], а здесь нам достаточно знать о ней, что она выполняет функцию «ангела-хранителя» конечного неслогового звука словоформы.

Типологически «охранительная» функция нашего ера аналогична функции французского e-muet, обеспечивающего произношение конечного согласного, в абсолютном конце слова (без «прикрытия» e-muet) не произносимого. То же происходит и в русском языке. Хотя конечный безударный $\boldsymbol{e}$ во французской речи не произносится, французы продолжают его обозначать на письме - в отличие от нас, пе-

${ }^{5}$ Термин «звучность» нами употребляется как дань традиции и знак нашей приверженности «волновой теории слога». Содержательно «звучность» трактуется нами как у с л о в н ы й в ес фона в слоге. Соответственно, восходящая «звучность» означает возрастание условных весов фонов в слоге, а нисходящая «звучность»- их убывание. Н. И. Жинкин говорил о слоговой дуге громкости: «....артикуляционные позиции различны от звука к звуку, а слоговая дуга однообразна - это подъем и падение, подъем и падение» [19, с. 226]. реставших писать $b$ в конце слов после согласных в 1918 г., видимо, следуя афоризму А. С. Пушкина: «Шпионы подобны букве ъ. Они нужны в некоторых только случаях, но и тут можно без них обойтиться, а они привыкли повсюду соваться». «Обойтиться» безь $b$, конечно, можно (правда, только на письме), но это проявление черной неблагодарности по отношению к трудолюбивым фонемам, добросовестно и незаметно выполняющим свою работу, связано с серьезными техническими и психологическими неудобствами.

Например, почему мы говорим времен_и, времен_ем, времен_а, времен_ами, времен_ах, но время? Потому что в этих падежах после основы следует гласный, предохраняющий конечный согласный от утраты. А в Именительном падеже основа *времен_ такого гласного не имеет. Как следствие, конечный /Н/, утрачивается, оставляя основе на память о себе носовой тембр предшествующего гласного: *времен_\#> *време ся за счет утраченного /н/, закономерным образом «опускается» из среднего в нижний подъем, реализуясь в виде А-переднего ряда и как следствие - смягчающего: /'a/, обозначаемого на письме после согласных буквой Я. Таким образом, словоформа время не состоит, как нас учат, из основы /вр'Ем'/ и окончания /a/, а является закономерной фонетической реализацией основы *времен_\#, не «защищенной» конечным гласным.

Тут самое время вспомнить про форму Р. П. мн. ч. времён, после которой с 1918 г. не обозначается нулевой вариант гласного $\{\mathrm{b}$, но который, тем не менее, продолжает защищать конечный /н/ от утраты. Отсюда такое различие: *времен_\# > время, а *времён_ъ > времён. Таким образом, Ђ - не «шпион», а «боец невидимого фронта», «гласный-невидимка» и «ангел-хранитель конечного согласного словоформы».

Несколько больше повезло ерю (букве b, обозначающей фонему Е-беглое: $\{\mathrm{b}\})$. Параллельную работу еря по смягчению предшествующего согласного заметили и (отчасти ${ }^{6}-$ по крайней мере на письме) признали, тогда как их с Ђ работа по сохранению конечного согласного слова так и осталась незамеченной и непризнанной. Отказ от написания Ђ в конце слова после согласных имел еще два отрицательных последствия: его функцию взял на себя символ пробела, ставший многозначным. До этого пробел обозначал только границу между словоформами, а с отказом от Ђ стал выполнять еще и функцию

\footnotetext{
${ }^{6}$ Oтчасти - потому что признак мягкости приписали предшествующему согласному, превратив тем самым неслоговой позиционный вариант фонемы в самостоятельную фонему и увеличив инвентарь русских неслоговых фонем почти вдвое.
} 
«охранения» конечного согласного. Как представители гласных В и Ь ведут себя и перед буквами Е, Ё Ю, Я: после них, как после обозначений общепризнанных гласных, эти буквы читаются как /йэ/, /йо/, /йу/, /йа/.

Таким образом, в слоге /c' т'ь/ представлена гласная фонема $\{\mathrm{b}\}$, закономерно реализованная в слабой позиции нулевым вариантом /'ø/. В словах на -/стъ/, -/скъ/ фонема \{ъ $\}$ столь же закономерно реализуется вариантом /ø/. Доказательством реальности нулевого фона в конце слова является сама сохранность конечных согласных, а в слоге /c'т'ь/ - еще и мягкость конечных согласных.

Для позитивистов-субстанциалистов есть еще 2 аргумента: после конечных -cm/cк приборы фиксируют гласный, а при произнесении «односложных» слов с этими финалями перед свечой, пламя колеблется не 1 , а 2 раза.

Все слоги с финалями 21 (TS) представлены в заимствованных словах: сакс, такс, кекс, икс, кникс, фикс, чикс, бокс, кокс, флокс, фокс, букс, фукс, экс, люкс; шнапс, panc, вепс, penc, степс, гипс, эл|липс, мопс, пупс и т. д.

Перейдем к рассмотрению двучленных финалей, содержащих сонанты.

Они строятся по модели (4/3)(2/1), т. е. RT, RS, NT, NS.

Bсе слоги с такими финалями встречаются в заимствованных словах (мнимые исключения в исконных словах будут обсуждены ниже): 31(NS): гнейс, пейс, рейс, гюйс; а-ванс, се-анс, станс, шанс, скунс, пенс, транс; бимс, 41(RS): арф, марш, фарс, галс; 42 (RT) альт; 32 (NT): бейт, флейт, войт, брандспойт: по-тамт, эк-спромт; бант, квант, кант, рант, франт, ну-ант, фант, а-гент, кли-ент, ичемент, тент, изент, бинт, винт, блинт, иплинт, флинт, спринт, финт, гонт, зонт, фронт, унт, бунт, грунт, ипунт, фрунт, фунт и др.

Слова с финалями -вm -/фpm/ - космо-навт, тера-певт, фарма-цевт, а также -гm -/кm/: фогт, -дm -/mm/: фор-штадm, шин-гардт и т. п. позволяют сделать вывод о том, что глухость является характеристикой отдельных фонов только для «легких» инициалей и финалей, а для «тя желы х» фина лей и инициалей глухость является инте гральной характеристикой неслоговых фонов, парных по глухости-звонкости . Как убедительно показала В. Г. Чурганова, «оглушение согласных на конце слова... соотносится непосредственно с концом слова, т. е. морфологичес кой границей» [17, с. 31-32].

Конечные фонетические «слоги», называемые А. И. Моисеевым ломаными, в фонемической интер-

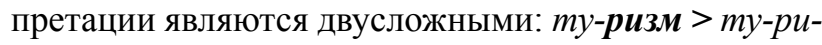

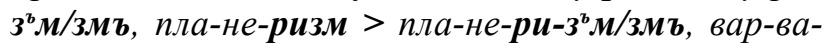

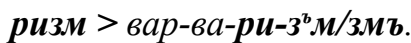

Слоги типа 5(3-4)(1-2) нуждаются в особом обсуждении, так как представляют собой конфликт между фонетическим (состоящем из фонов) и фонематическим (состоящим из фонем) слогом.

Исконные слова с фонетической финалью RT, RS : $c^{e} p n, c m^{\circ} л б, \kappa^{\circ} p ж, c м^{e} p m b, в^{e} p x$ и т. д. имеют в качестве инициалей слоговые варианты сонантов, представленные на поверхности сочетаниями /op/, /ол/, /ep/, ел/, поэтому фонемическая финаль у них одночленная: T/S, а структура слога (1/2)5(2/1). В предельно обобщенном представлении - (c)cГс.

Интересны случаи сонантно-консонантного дуа-

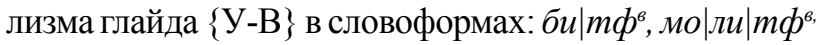

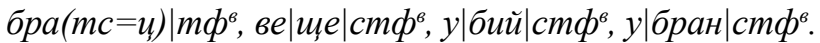

На поверхности представлены финали 21 /тф/, в и 121 /стф/. Фонемически же это отдельные слоги

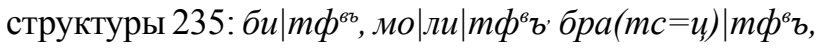

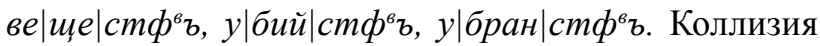
вызвана противоречием между фонемикой и морфонологией, представляющей интересы морфологии: консонантный конец русского слова должен быть глухим - это сигнал конца слова, поэтому слог строится по законам фонемики: (1)235, а реализуется по законам морфонологии: (1)215.

В словоформе $a|2 е н| m c m s^{b}$ реально произносится не $/ ц=\mathrm{Tc} /$, a /c/: [a| $\Gamma^{\prime} Э \mathrm{H} \mid$ ст $\left.^{\mathrm{B}}\right]$. По законам русского языка никак иначе это произноситься и не может. Последний фонемический слог 1235=STNA.

Слогами с трехчленными финалями А. И. Моисеев считает тек $\mid c m$, пунк $\mid m$, цен $\mid$ тр и т. п. Но во-первых, это заимствованные слова, а во-вторых, все они фонемически двусложны: тек|cmъ, пунк|mъ, цеен|тръ.

В слове цзентр финаль может реализовываться и в модели $25=\mathrm{T}^{\mathrm{v}} \mathrm{R}-$ иен $\mid m^{e} p$ :

а в стену бил рукой Тюльпанов

звал напрасно цент/е]р сил

рас над камнем сад тюльпанов

дождик светльй моросил. (НКРЯ)

[Д. Хармс. Тюльпанов среди хореев (1929)]

Фонетически трехчленная финаль 321=NTS представлена в заимствовании сфинкс. Примечательно, что в греческом, из которого воспринято это слово, /кс/ является аффрикатой, и следовательно, в нем финаль двучленна: 32=NT. Приводимые А. И. Моисеевым примеры спек|тр, мон|стр 2-сложны.

Различение вос-ходящих, нис-ходящиих и вос-ходяще-нис-ходящих слогов следует принять и ввести в употребление: они компактны, понятны, удобны, ибо характеризуют слог в целом, а не по началу (прикрытый-неприкрытый) и концу (открытый-закрытый) порознь.

Для полноты картины следует применить к одночленным (неприкрытым открытым) слогам типа э-то, $\boldsymbol{u}$-дy, $\boldsymbol{a}$-то, $\boldsymbol{o}$ - $c a, \boldsymbol{y}$ - $x a$ и т. п. термин «неподвижные» или «стоящие», что вполне соответствует не- 
изменности их звучности и антонимично «-ходящим» (воз-/низ-) слогам.

Предложенный А. И. Моисеевым для чисто вокальных слогов термин ровные слоги неудачен тем, что: 1) ровность подразумевает протяженность, а слог из одного вокала - скорее точка, чем отрезок прямой; 2) это же прилагательное применяется к «равнозвучности» двух соседних фонов при характеристике «-ходящих» слогов: «Слоги с тяжелыми началами и концами имеют обычно более сложный акустический рисунок: ровно-восходящий (cmo), нисходяще-ровный (иск), нисходяще-восходящий (мгла), восходяще-нисходяще-ровный (воск), восходяще-нисходяще-восходящий (вобл) и другие» [5, с. 114].

Следующие типы слогов, выделяемые А. И. Моисеевым, демонстрируют несостоятельность приравнивания инициали/финали слога к инициали/финали («односложного») слова:

нисходяще-восходящиий (м|гла)

восходяще-нисходяще-ровный (во $\mid с \kappa)$

восходяще-нисходяще-восходящчий (во|бл)

Идя таким путем, можно обнаружить и нисходящзе-восходяще-нисходяще-ровный слог: $м \mid$ гли|cm
звучность:
324512

... в низинках дороги воздух был мглист, прохладен и упруг... [Дмитрий Каралис. Роман с героиней // Звезда. 2001] (НКРЯ)

Воздух мглист и тяжел, в нем стоит серая мгла, гарь. [А. В. Туркул, И. С. Лукаш. Дроздовцы в огне (1937-1948)] (НКРЯ)

Пьэтливо смотрю я на горизонт, надеясь увидеть препятствие, о которое ломается лед, - остров, желанный остров, но, увы, ничего не вижу. Правда, горизонт мглист, а погода пасмурна... [В. И. Альбанов. Дневник (1914)] (НКРЯ)

Между /м/ и /г/ есть беглый гласный: ст.-слав. мьгла, др.-русск. мьгла, мегла, мъгла [20, т. 9, 51-52], рус. диал. псковск. мугла́, блр. диал. полесск. мугла́, укр. диал. закарпатск. мо́лга́. [11, т. 21, с. 93-94].

Таким образом, форма малист имеет три слога: мъ-гли-сть, и все они восходящие.

\section{Заключение}

Из 25 теоретически возможных структурных типов слогов, по данным А. И. Моисеева, реализовано 20 (преимущественно в составе односложных слов), а по нашим данным - 9 (табл. 1) (многосложные и заимствованные типы помечены символом «*»):

1) Г: А! O! Э! A-y! o|на, y|дар? (o|a|зис, э|хо и т. п.);

2) сГ: щии, mbl, да, мbl, pa-бо-та, пе-ре-ра-бо-тали и т. п.;

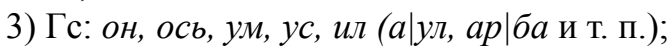

4) ссГ: сто, три, два, сна, спи (бра, бра|во и т. п.);
5) сГс: сон, дом, рам-(ка), лод|ка (ром, пар (та) и т. п.);

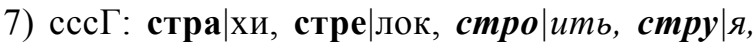
здра|ви|иза, но|здря (м|гла, в|ста|вать и т. п.);

8) ссГс: стол, стой, стон, стул, стой-(ко), cmap-(иий) и т. п.;

12) сссГс: страх, страж, стран|ный и т. п.;

15) ссссГс: (осуще)-ствлять (в|згляд, в|стреч и т. п.);

*6) Гсс: $u|c \kappa ъ, y| c m b, o|c n ъ, o| c m b$ (акm, альт и т. п.);

*9) сГсс: мо|cm, ме|cmb, ве $\mid c m b$, че $\mid c m b,(p a)$ до $\mid$ сть, парк и т. п.;

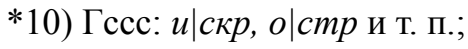

*11) ссссГ: $\phi^{6} ъ \mid$ стре $\mid$ ча, $\phi^{6}$ ъ $\mid$ спле $\mid$ ски и т. п.;

*13) сГссс: пун $\left|\kappa m, n^{e} p\right| c m$, тек $\mid c m$, филь $\mid$ тр и т. п.;

*14) ссГсс: сm $^{\circ} б$, y|кра|cmъ (сnорm, па|cnopm и т. п.);

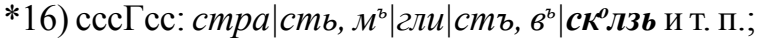

*17) ссГссс: спек|тр, сфинкс и т. п.;

*18) сГсссс: мон $\mid$ стр, (сви $\mid$ де)-тель $\mid$ ств и т. п.;

*19) ссссГсс: $\boldsymbol{B}^{\text {ъ }} \mid$ спле $\mid c \kappa, в^{\text {ъ }}$ збле $\mid$ ск и т. п.;

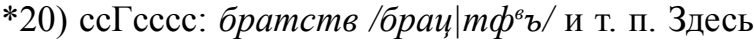
работает 4-е правило (Цементирующей функции слога): 2-е правило (Приоритет восходящей звучности) обходится посредством аффрикаты /ц=тс/ с условным весом 2.

Т а б ли и а 1

Типы фонемических слогов

в современном русском литературном языке

\begin{tabular}{|c|c|c|}
\hline № & Тип слога & Пример \\
\hline 1 & V & а \\
\hline 2 & CV & он \\
\hline 3 & VC & дом \\
\hline 5 & CVC & сто, (зве)зда \\
\hline 4 & CCV & стол \\
\hline 6 & CCVC & скло, стра(хи), (се)стра \\
\hline 7 & CCCV & строй \\
\hline 8 & CCCVC & (о|су|ще)ствля(ет) \\
\hline 9 & CCCCV & (о|су|ще)ствлял \\
\hline 10 & CCCCVC & \\
\hline
\end{tabular}

Различение фонетических и фонемических слогов позволило перейти от наблюдения и констатации, представленных в исследовании А. И. Моисеева, к сущности и объяснению, связанных с фонемическими слогами.

${ }^{7}$ «СКЛО, СТКЛО Устар. и обл. Стекло» [12, т. 25, с. 681]. 
Выяснилось, что многие одновокальные слова являются фонемически многосложными.

Оказалось возможным обнаруживать фонемы, реализуемые нулем звука, но выполняющие при этом свои функции.

Размер фонемической инициали - 0-4, а размер фонемической финали исконных слов - 0-1. Теоретически возможное количество комбинаций -10 . Из них реализовано 9 (табл. 2).

Т а блиц а 2

Реализация теоретически возможных структур слога по данным А. И. Моисеева

\begin{tabular}{|c|c|c|c|c|c|}
\hline № & Фонем & Инициаль & Медиаль & Финаль & Пример \\
\hline 1 & 1 & 0 & 1 & 0 & а \\
\hline 2 & 2 & 1 & 1 & 0 & на \\
\hline 3 & 2 & 0 & 1 & 1 & ось \\
\hline 4 & 3 & 2 & 1 & 0 & сто \\
\hline 5 & 3 & 1 & 1 & 1 & сон \\
\hline 6 & 4 & 3 & 1 & 0 & $\begin{array}{c}\text { скло, } \\
\text { (осуще)стви }\end{array}$ \\
\hline 7 & 4 & 2 & 1 & 1 & стой \\
\hline 8 & 5 & 4 & 1 & 0 & (осу|ще)ствля(ли) \\
\hline 9 & 5 & 3 & 1 & 1 & строй \\
\hline 10 & 6 & 4 & 1 & 1 & (осуще)ствлял \\
\hline
\end{tabular}

Обнаружены ударные дифтонги с плавными сонантами ОР, ЕР, ОЛ, ЕЛ. Безударные сонанты образуют слоги факультативно: слоговой и неслоговой варианты безударного сонанта находятся в отношениях свободного варьирования. При этом вокалические пазвуки сонантов ведут себя подобно редуцированным $\{\mathrm{b}\}$ и $\{\mathrm{b}\}$.

Установлено, что слог в русском языке выполняет двуединую морфонологическую функцию: во-первых, объединяет (по образному выражению И. А. Бодуэна де Куртенэ, «цементирует») морфемы в слова (исключение составляют приставки, равные открытому слогу, энклитики, например -ся, и архаичный суффиксальный стык глагола после степенных суффиксов: = $y$, $=u,=e,=a$; во-вторых, совпадение границ слога и морфемы является сигналом границы слов (единственное исключение - архаичная позиция после степенных суффиксов глагола).

Таким образом, сам язык свидетельствует, что так называемый «постфикс» -ся является самостоятельным словом и самостоятельным членом предложения, а отрицательные частицы не (некто), ни (никто) и глагольные приставки с гласным в финали так и не стали частью современного русского слова (сколько бы мы их ни писали слитно).

В целом исследование А. И. Моисеева наглядно демонстрирует несостоятельность прецедентного метода слогоделения, исходящего из непременно- го тождества начала-конца слова и начала-конца слога.

\section{ЛИТЕРАТУРА}

1. Соссюр Ф. де. Труды по языкознанию / пер. с фр. яз., под ред. А. А. Холодовича ; ред. М. А. Оборина ; предисл. проф. Н. С. Чемоданова. М. : Прогресс, 1977. 696, [2] с. (Языковеды мира.)

2. Курилович Е. Очерки по лингвистике : сб. ст. : [пер. с пол., фр., англ., нем.]. М. : Изд-во иностр. лит., $1962.456 \mathrm{c}$.

3. Фасмер М. Этимологический словарь русского языка : в 4 т. / пер. с нем. и доп. О. Н. Трубачева. 4-е изд., стер. М. : Астрель : Издательство АСТ, 2004.

4. Аванесов Р. И. О слогоразделе и строении слога в русском языке // Вопросы языкознания. 1954. № 6. C. $88-101$.

5. Моисеев А. И. Типология слогов в современном русском литературном языке // Вопросы языкознания. 1975. № 6. С. 109-115.

6. Словарь русского языка : в четырех томах. М. : Гос. изд-во иностр. и нац. словарей, 1957-1961.

7. Панов М. В. Современный русский язык. Фонетика : учебник для ун-тов. М. : Высш. школа, 1979. $256 \mathrm{c}$.

8. Панов М. В. О слогоделении в русском языке // Проблемы фонетики II : сб. ст. / отв. ред. Л. Л. Касаткин. М., 1995. С. 29-42.

9. Бурлак С. А., Старостин С. А. Сравнительноисторическое языкознание : учебник для студ. высш. учеб. заведений. М. : Академия, 2005. 432 с.

10. Щерба Л. В. Фонетика французского языка. Очерк французского произношения в сравнении с русским. Изд. третье, испр. и расшир. М. : Изд-во лит-ры на иностр. языках, 1948. 288 с.

11. Этимологический словарь славянских языков : (праславянский лексический фонд). М. : Наука, 1974-2018. Вып. 1-41.

12. Большой академический словарь русского языка. М. ; СПб. : Наука, 2004- ... Т. 1-...

13. Кретов A. А. Два принципа устройства мирозданья и языка // Грамматика III тысячелетия в контексте современного научного знания : XXVIII Pacпоповские чтения : материалы Междунар. конф., посвящ. 50-летию со дня основания кафедры русского языка филологического факультета ВГУ, 85-летию со дня рождения проф. И. П. Распопова, 75-летию со дня рождения проф. А. М. Ломова (Воронеж, 12-14 марта 2010 г.) : в 2 ч. Воронеж : ВГПУ, 2010. Ч. 1. C. 17-26.

14. Словарь русских народных говоров. Вып. 25 (Отчурить - Первачок). Л. : Наука, 1990. 352 с.

15. Руделев В. Г. Фонологическое обоснование слогораздела в русском языке // Руделев В. Г. Собрание сочинений : в 6 т. Т. 6. Друг мой - язык. Избран- 
ные произведения по общему и русскому языкознанию. Ч. 1. Тамбов : Изд-во ТГУ им. Г. Р. Державина, 2002. C. 84-98.

16. Аникин A. E. Русский этимологический словарь. М. : Ин-т рус. яз. им. В. В. Виноградова РАН ; Ин-т филологии Сибирского отделения РАН ; СПб. : Нестор-История, 2020. Т. 14. 384 с.

17. Чурганова В. Г. Очерк русской морфонологии. М. : Наука, 1973. 239 с.

18. Кретов $A$. A. Системная русская фонемология : монография. Воронеж : Издательский дом ВГУ, 2020. 222 с. (Системная русская лингвистика ; Т. 1.)

19. Жинкин Н. И. Механизмы речи. М. : Изд-во Академии педагогических наук, 1958. 370 с.

20. Словарь русского языка XI-XVII вв. / АН СССР, Ин-т рус. яз. ; редкол.: С. Г. Бархударов (отв. ред.) [и др.]. М. : Наука, 1975-... . Т. 1-...

\section{REFERENCES}

1. Sossur F. de. Trudy po jazykoznaniju [Works on Linguistics]. Perevod s francuzskogo jazyka, pod redakcijei A. A. Kholodovicha; Redaktor M. A. Oborina; Predislovije prof. N. C. Chemodanova. Moscow: Progress, 1977. 696, [2] p. (Jazykovedy mira).

2. Kurilovich E. Ocherki po lingvistike: sb. statej [perevod s pol'skogo, fr., angl., nem.]. M. : Izd-vo inostr. lit., 1962. $456 \mathrm{p}$.

3. Fasmer M. Slovar' russkogo jazyka [Russian Etymology Dictionary]: v 4 tomakh. Moscow: Astrel Press: AST Press, 2004.

4. Avanesov R. I. O slogorazdele i strojenii sloga v russkom jazyke [On syllable division and syllable composition in Russian language]. In: Voprosy jazykoznanija. 1954. No. 6. Pp. 88-101.

5. Moiseev A. I. Tipologija slogov v sovremennom russkom literaturnom jazyke [Typology of Syllables in Modern Standard Russian]. In: Voprosy jazykoznanija. 1975. No. 6. Pp. 109-115.

6. Slovar' russkogo jazyka v chetyr'okh tomakh [Russian Dictionary in four volumes]. Moscow: Foreign and National Dictionaries State Press. 1957-1961.

7. Panov M. V. Sovremennyj russkij jazyk. Fonetika [The Modern Russian Language. Phonetics]: Uchebnik dl'a universitetov. Moscow: Higher Education, 1979. $256 \mathrm{p}$.

8. Panov M. V. O slogodelenii v russkom jazyke [On syllable division in the Russian language]. In: Problemy fonetiki II. Sbornik statei. Otvetstvennyi redaktor L. L. Kasatkin. Moscow, 1995. Pp. 29-42.

9. Burlak S. A., Starostin S. A. Sravnitel'no-istoricheskoje jazykoznanije [Historical linguistics]: Uchebnik dl'a studentov vusshikh uchebnykh zavedenij. Moscow: Akademija, 2005. 432 p.
10. Shcherba L. V. Fonetika frantsuzskogo jazyka. Ocherk frantsuzskogo proiznoshenija $\mathrm{v}$ sravnenii $\mathrm{s}$ russkim [French phonetics. Essay on French pronunciation as compared to Russian one]. Moscow: Foreign literature Press, 1948. 288 p.

11. Etimologicheskij slovar' slav'anskikh jazykov: (praslav'anskij leksicheskij fond) [Slavic Etymology Dictionary: (the Proto-Slavic language)]. Moscow : Science, 1974-2018. Issues 1-41.

12. Bol'shoj akademicheskij slovar' russkogo jazyka [The Great general-purpose Russian dictionary]. Vol. 1-... Moscow; St. Petersburg : Nauka, 2004-...

13. Kretov A. A. Dva printsipa ustrojstva mirozdanja i jazyka [Two principles of the world and language arrangement]. In: Grammatika III tys'acheletija v kontekste sovremennogo nauchnogo znanija: XXVIII Raspopovskije chtenija : materialy Mezhdunarodnoj konferencii, posv'aschonnoj 50-letiju so dn'a osnovanija kafedry russkogo jazyka filologicheskogo fakul'teta $V G U$, 85-letiju so dn' a rozhdenija prof. I. P. Raspopova, 75-letiju so dn'a rozhdenija prof. A. M. Lomova (Voronezh, 12-14 marta 2010 g.) : in 2 vol. Voronezh: VGPU, 2010. Vol. 1. Pp. 17-26.

14. Slovar' russkikh narodnykh govorov [Dictionary of Russian Vernaculars], Issue 25. (Otchurit'-Pervachok). Leningrad: Science, 1990. 352 p.

15. Rudel'ov V. G. Fonologicheskoje obosnovanije slogorazdela v russkom jazyke [Phonemic objectivation of syllable boundary in the Russian language]. In: Rudel'ov V. G. Sobranije sochnenij v 6 tomakh. T. 6. Drug moi - jazyk. Izbrannyje proizvedenija po obshchemu i russkomu jazykoznaniju. Chast' 1 . Tambov: TSU named after G. R. Derzhavin Press, 2002. Pp. 84-98.

16. Anikin A. Ye. Russkij etimologicheskij slovar' [Russian Etymology dictionary]. Vol. 14. Moscow: Institut russkogo jazyka imeni V. V. Vinogradova RAN; Institut filologii Sibirskogo otdelenija RAN; St. Petersburg: Nestor-Istorija, 2020. 384 p.

17. Churganova V. G. Ocherk russkoj morfonologii [Essay on Russian morphophonemics]. Moscow : Science, 1973. 239 p.

18. Kretov A. A. Sistemnaja russkaja fonemologija [Systematic Russian phonemics]: monografija. Voronezh : Publishing House 'VSU', 2020. 222 p. (Systemnaja russkaja lingvistika; T. 1).

19. Zhinkin N. I. Mekhanizmy rechi [How speech works]. Moscow: Academy of Pedagogical Sciences Press. 1958. 370 p.

20. Slovar' russkogo jazyka XI-XVII vv. [Dictionary of the Russian language of XI-XVII centuries]. T. 1-... Moscow : Science, 1975-... 
Воронежский государственный университет Кретов А. А., доктор филологических наук, профессор кафедры теоретической и прикладной лингвистики E-mail:kretov@rgph.vsu.ru

Поступила в редакцию 2 сентября 2021 2. Принята к публикации 15 октября 2021 2.

\section{Для циитирования:}

Кретов А. А. Прецедентный метод слогоделения и типы фонетических и фонемических слогов в современном русском литературном языке // Вестник Воронежского государственного университета. Серия: Лингвистика и межкультурная коммуникация. 2021. № 4. C. 135-145. DOI: https://doi.org/10.17308/lic.2021.4/3821
Voronezh State University

Kretov A. A., Doctor of Philology, Professor of Theoretical and Applied Linguistics Department

E-mail:kretov@rgph.vsu.ru

Received: 2 September 2021

Accepted: 15 October 2021

\section{For citation:}

Kretov A. A. Precedent method of syllable division and types of phonetic and phonemic syllables in modern standard Russian. Proceedings of Voronezh State University. Series: Linguistics and Intercultural Communication. 2021. No. 4. Pp. 135-145. DOI: https://doi.org/10.17308/lic.2021.4/3821 